\title{
RECAPTURING THE SPIRIT OF FURMAN: THE AMERICAN BAR ASSOCIATION AND THE NEW ABOLITIONIST POLITICS
}

\author{
A USTIN SARAT* \\ I \\ INTRODUCTION
}

When, in 1972, the Supreme Court halted executions-finding the application of the death penalty incompatible with the Eighth A mendment's prohibition of cruel and unusual punishment ${ }^{1}$ - many in the anti-capital punishment movement saw it as the penultimate step in a long struggle to end state killing. ${ }^{2}$ They were confident that the Furman opinions of J ustices B rennan and M arshall pointed the way toward an impending judicially imposed abolition of capital punishment, and they carefully plotted the steps necessary to bring that result to fruition. A s Philip K urland wrote at the time:

O ne role of the Constitution is to help the nation to become "more civilized." A society with the aspirations that ours so often asserts cannot consistently with its goals, coldly and deliberately take the life of any human being no matter how reprehensible his past behavior. ... In the Furman v. G eorgia decision the inevitable came to pass. ${ }^{3}$

J ack $G$ reenberg of the N A A CP L egal D efense F und expressed a similar understanding of the significance of F urman when he said, "There will no longer be any more capital punishment in the U nited States."

From the perspective of a quarter century later, these predictions look quite naïve as well as somewhat forlorn. A s is now well known, after Furman something unexpected happened. Whereas in other W estern nations the abolition of the death penalty was followed by a downturn in public interest and support for capital punishment, ${ }^{5}$ in Furman's wake, a dramatic pro-capital punishment backlash occurred. "State legislatures ... quickly responded to the Court's de-

Copyright $\odot 1998$ by L aw and Contemporary Problems

This article is also available at http://www.law.duke.edu/journals/61L CPSarat.

* William Nelson Cromwell Professor of J urisprudence \& Political Science, A mherst College; President, Law and Society A ssociation.

1. See Furman v. G eorgia, 408 U .S. 238, 239-40 (1972).

2. See, e.g., H ugo A dam Bedau, Challenging the D eath Penalty, 9 HARV. C.R.-C.L. L. REV. 624 (1974) (reviewing Michael Meltsner, Cruel and Unusual: The Supreme Court and CA PITA L PUNISHMENT (1973)).

3. Philip K urland, 1971 Term: The Y ear of the Stewart-White C ourt, 1972 SU P. CT. R E V. 181, 29697 (1972)

4. Michael Meltsner, Cruel and Unusual: the Supreme Court and Capital PUNISHMENT 291 (1973).

5. See Franklin E. Zimring \& GORdon hawkins, Capital Punishment and the A MERICAN A GENDA 12-15 (1986). 
cision, but instead of conducting a thorough reevaluation of the subject, they enacted whatever statutory revisions they perceived as correcting the constitutional flaws contained in pre-Furman capital laws." ${ }^{6}$ Public reaction followed a similar pattern, "with a hostile response all over the country." ${ }^{77}$ Thus, four years after Furman's limited abolition of capital punishment, the Court, in G regg v. G eorgia, ${ }^{8}$ found that "it is now evident that a large proportion of A merican society continues to regard [capital punishment] as an appropriate and necessary criminal sanction." ${ }^{9}$ A s a result, the Court held that "the punishment of death does not invariably violate the Constitution." ${ }^{10}$

Since the mid-1970s, the political and legal climate for abolition of the death penalty has grown progressively more hostile. Proponents of capital punishment have responded to Furman with a mean-spirited revisionism. ${ }^{11}$ Procedural guarantees once thought minimally necessary to secure fairness and reliability in capital sentencing have been openly and enthusiastically jettisoned. A merican society seems even more impatient with the procedural niceties and delays attendant to what many now see as excessive scrupulousness in the handling of capital cases. What good is having the death penalty, so the refrain goes, if there are so few executions? ${ }^{12}$ Blood must be let; lives must be turned into corpses; the charade of repeated appeals prolonging the lives of those on death row must be brought to an end. In response, numerous recent decisions of the Supreme Court have eroded, not enhanced, the procedural integrity of the death sentencing process. ${ }^{13}$

The Court has moved rather methodically, if not in a linear fashion, to cut off all systemic, "wholesale" challenges to the constitutionality of capital punishment. ${ }^{14}$ A nd public support for the death penalty has risen virtually to unprecedented levels. Today most national polls show support in the seventy to

6. Id. at 41 .

7. Id. at 42 .

8. 428 U .S. 153 (1976).

9. Id. at 179 .

10. Id. at 169 .

11. For an example of the premises that produce such revisionism, see L ewis F. Powell, J r., Commentary: Capital Punishment, 102 H A RV. L. REV. 1035, 1039 (1989). For an illuminating discussion of this mean-spirited revisionism, see A nthony A msterdam, Selling a Quick Fix for B oot H ill: The M yth of J ustice Delayed in Death Cases, in THE KILLING STA TE: CA PITA L PUNISHMENT IN LA W, POLITICS, A ND CULTURE (A ustin Sarat ed., 1999).

12. For an interesting argument about the execution rate, see Samuel R. G ross, The Romance of Revenge: Capital Punishment in A merica, 13 STU D. L. POL. \& SO C'Y 71, $92-99$ (1993).

13. See, e.g., Penry v. L ynaugh, 492 U .S. 302 (1989); T eague v. L ane, 489 U .S. 288 (1989).

14. See R obert W eisberg, D eregulating D eath, 1983 SU P. CT. REV. 305; see also A nthony G. A msterdam, In Favorem M ortis: The Supreme Court and Capital Punishment, 14 H U M. R TS. 14 (1987). Here perhaps the most important rebuff to the "wholesale" approach occurred in M cCleskey v. K emp, in which the Court refused to invalidate the death penalty even in the face of statistical evidence of systemic racial disparities in the administration of capital punishment. See 481 U.S. 279, 298 (1987). A s William B owers argues, "The Court's ruling in M CCleskey meant that the kind of evidence that would suffice to save M cCleskey's job could not save his life." See William Bowers, Capital Punishment and Contemporary Values: People's M isgivings and the Court's M isperceptions, $27 \mathrm{~L}$. \& So 'Y REV . 157, 158 (1993). 
seventy-five percent range. ${ }^{15}$ The political and public appetite for legally imposed death seems almost insatiable; ${ }^{16}$ where once an execution was the stuff of front page and television evening news coverage, today, except in unusual circumstances, execution has been routinized. ${ }^{17}$ Politicians of every stripe do not want to be caught on the "wrong side" of the death penalty debate. ${ }^{18}$ A bolition now has meager support, and the abolition movement has become virtually invisible. $^{19}$

If that were not enough, courts have grown impatient with the complex legal process the Supreme Court constructed to ensure fairness in the administration of law's ultimate penalty. ${ }^{20}$ In recent years, in an apparent effort to limit the reach of the $E$ ighth $A$ mendment as a source of protection for capital defendants, the Supreme Court has gradually cut back on the availability of federal habeas corpus relief in death penalty cases. ${ }^{21}$ Through decisions dealing with procedural default, ${ }^{22}$ exhaustion, ${ }^{23}$ and abuse of the writ through the filing of successive habeas petitions, ${ }^{24}$ the Court has made it increasingly difficult for lower federal courts to reach the merits of a defendant's habeas claims.

Some years ago, in one of the most significant of these cutbacks, the Court declared that defendants must generally base their habeas petitions on asserted violations of the federal law as it existed at the time of the original state proceedings. ${ }^{25}$ In a follow-up case, it held that if the federal law was unclear at that

15. For a discussion of the nature of public opinion about the death penalty, see Bowers, supra note 14, at 162; A ustin Sarat \& Neil Vidmar, Public O pinion, the Death Penalty, and the Eighth A mendment: Testing the Marshall Hypothesis, 1976 WIS. L. REV. 171; see also Robert M. Bohm, A merican Death Penalty Opinion, 1936-1986: A Critical Examination of the Gallup Polls, in THE Death Penalty in A merica: CuRRent ReSEARCH 113 (Robert M. Bohm ed., 1991).

16. See Bowers, supra note 14 , at 157,162 . Wendy Lesser argues that there is a "crucial connection between murder and theater - between death imposed on a human being by another human being, and dramatic spectacle." WENDY LESSER, PICTURES AT AN EXECUTION: AN INQUIRY INTO THE SUBJECT OF MURDER 7 (1993).

17. See Susan Blaustein, Witness to A nother E xecution: In Texas, D eath Walks an A ssembly Line, HARPER'S, M ay 1994, at 53; see also A ustin Sarat, K illing M e Softly: Capital Punishment and the Technologies of Death, in COURTING DEATH: THE LEGAL CONSTRUCTION OF MORTALITY (D esmond $M$ anderson ed., forthcoming 1999).

18. For a discussion of Bill Clinton's concerted efforts to stay on the "right side" of the death penalty issue, see M arshall Frady, D eath in A rkansas, NEW Y OR KER, Feb. 22, 1993, at 105.

19. See M ichael O reskes, The Political Stampede on Execution, N.Y. TIM ES, A pr. 4, 1990, at A 16.

20. That process is described by Jack Greenberg, The Capital Punishment System, 91 Y A LE L.J . 908 (1982); Franklin E. Zimring, Inheriting the Wind: The Supreme Court and Capital Punishment in the 1990s, 20 FLA. ST. U. L. REV. 7 (1992).

21. The Court has long viewed itself as having the authority to alter the scope of federal habeas, even without new legislation. See W ainwright v. Sykes, 433 U .S. 72, 81 (1977) (referring to the Court's "historic willingness to overturn or modify its earlier views of the scope of the writ, even where the statutory language authorizing judicial action has remained unchanged").

22. See Wainwright, 433 U.S. at 72.

23. See R ose v. Lundy, 455 U .S. 509 (1982).

24. See M cCleskey v. Zant, 499 U .S. 467 (1991).

25. See Teague v. L ane, 489 U .S. 288,310 (1989). The portion of J ustice O 'C onnor's lead opinion in Teague referred to in the text garnered only three other votes, and thus is technically only a plurality opinion. H owever, in the subsequent case of Penry v. L ynaugh, 492 U .S. 302 (1989), J ustice O 'Connor picked up the additional vote of J ustice White, who had refused to join the relevant portion of her 
time, any reasonable, "good faith" interpretation of the federal law by the state courts immunizes the conviction and sentence from later habeas attack. ${ }^{26}$ E ven more recently, the Court extended the same principle to the method of application of the federal law to the facts of a particular case; if the state court's method of application was proper in view of the precedents that existed at that time, then federal habeas relief is unavailable, even if those precedents are later overruled or changed. ${ }^{27}$

These decisions have already made it much more difficult for a defendant who receives a death sentence to obtain federal habeas review of the merits of whatever decisions or rulings might have been made by the judge during his capital trial. ${ }^{28}$ So hostile have the courts become to extended litigation in capital cases that in one case where there had been repeated last minute requests for a stay of execution in several different courts, the Supreme Court usurped the legal prerogatives of the lower courts and took the unprecedented step of ordering that no further stays be granted. ${ }^{29} \mathrm{E}$ ven new evidence of actual innocence has been found to be inadequate as the basis for challenging a death sentence. $^{30}$ For the current Supreme C ourt, "finality is more important than hearing every meritorious legal claim; there simply comes a point when legal proceedings must end and punishment must be imposed." ${ }^{31}$ Moreover, two years ago, Congress delivered a one-two punch directed against those who continue to oppose the death penalty, first enacting Title I of the A nti-Terrorism and $E$ ffective Death Penalty A ct, which severely limited the reach of federal habeas corpus protections for those on death row, ${ }^{32}$ and then de-funding PostConviction Defender Organizations, which provided legal representation for many of those contesting their death sentences. ${ }^{33}$

L ittle did abolitionists realize that Furman would be the legal and political highwater mark of their efforts and that, a quarter century later, they would

opinion in Teague. Thus, the relevant portion of J ustice $\mathrm{O}^{\prime} \mathrm{C}$ onnor's opinion now represents the views of a majority of the Court.

26. See B utler v. M cK ellar, 494 U .S. 407, 414 (1990).

27. See Stringer v. B lack, 503 U .S. 222, 228 (1992).

28. See Steven M. G oldstein, Chipping A way at the Great Writ: Will D eath Sentenced Federal Habeas Corpus Petitioners Be A ble to Seek and Utilize Changes in the Law?, 18 N.Y.U. REV. L. \& SoC. CHANGE 357 (1990-91); J ames Liebman, M ore Than "Slightly Retro": The Rehnquist Court's Rout of Habeas Corpus J urisdiction in Teague v. Lane, 18 N.Y.U. REV. L. \& SOC. CHA NGE 537 (1990-91). See generally Steven M. G oldstein, Expediting the Federal H abeas Corpus Review Process in Capital Cases: An Examination of Recent Proposals, 19 CA P. U. L. REV. 599 (1990) (discussing various legislative proposals to restrict federal habeas).

29. See V asquez V. H arris, 503 U .S. 1000 (1992); see also Stephen R einhardt, The Supreme Court, The D eath Penalty, and The H arris Case, 102 Y A LE L.J . 205 (1992).

30. See Herrera v. Collins, 506 U .S. 390, 398 (1993). In response to Herrera, J ustice Blackmun charged the Court with coming "perilously close to murder." Id. at 446 (B lackmun, J ., dissenting).

31. Evan Caminker \& Erwin Chemrinsky, The Lawless Execution of Robert Alton $\mathrm{H}$ arris, 102 Y A LE L.J . 225, 226 (1992). "[T] ]he Court's desire to expedite the process of death ... has now accrued a life of its own." Id. at 253; see also J oseph L. H offman, I I nnocence Sufficient? A n E ssay on the U.S. Supreme Court's Continuing Problems with Federal $\mathrm{H}$ abeas Corpus and the D eath Penalty, 68 IND. L.J . 817 (1993).

32. Pub. L. N o. 104-132, 110 Stat. 1214 (1996).

33. See H arvey B erkman, Costs M ount for Indigent D efense, N A T'L L.J ., A ug. 7, 1995, at A 18. 
still be fighting to recapture the terrain that Furman defined, a terrain I have elsewhere called "abolitionism as legal conservatism." ${ }^{34}$ on this terrain, the campaign to abolish capital punishment no longer takes the form of a frontal assault on the morality or constitutionality of state killing. Instead, arguments against the death penalty occur in the name of constitutional rights other than the E ighth A mendment, in particular due process and equal protection. A bolitionists today argue against the death penalty claiming that it has not been, and cannot be, administered in a manner that is compatible with our legal system's fundamental commitments to fair and equal treatment.

This article locates the A merican Bar A ssociation's ("A B A 's") recent call for a moratorium on executions ${ }^{35}$ in the context of contemporary abolitionist politics. It shows how the new abolitionism fuels the work of many in the antideath penalty community today even as they confront an increasingly hostile political and legal environment. The article argues that the new abolitionism links anti-death penalty work with a broader civil rights agenda and helps sustain what I label "democratic optimism" in the face of the bleakness of the present moment. These arguments are developed by reporting on the attitudes of a small group of lawyers who specialize in representing people on death row and who are today the core of the abolitionist movement. ${ }^{36}$ The article concludes by noting that while the A BA is a relative latecomer to the new abolitionist politics, its entry into the fray is, nonetheless, quite significant. The A BA resolution legitimates arguments often dismissed as mere partisan attempts to erect "technical" roadblocks on the path from death sentences to executions and lends important symbolic capital to death penalty opponents.

II

\section{THE "NEW A BOLITIONISM" 37}

In February 1994, J ustice Harry B lackmun of the U nited States Supreme Court wrote, "From this day forward I no longer shall tinker with the machinery of death." ${ }^{38}$ This dramatic proclamation capped his evolution from longtime supporter of the death penalty, to tinkerer with various procedural schemes and devices designed to rationalize death sentences, and then to outright abolitionist. Twenty-two years before his abolitionist announcement, Blackmun dissented in Furman v. Georgia, refusing to join the majority of his

34. A ustin Sarat, A bolitionism as L egal Conservatism: The A merican Bar A ssociation, the D eath Penalty, and the Continuing Anxiety About Law's Violence, 1.2 THEORY \& EVENT 5 (1997) <http://muse.jhu.edu/journals/theory_\& event/v001/1.2sarat.html>.

35. See A merican Bar A ss'n, R esolution of the House of D elegates (Feb. 1997), reprinted in A ppendix, 61 LA W \& CONTEMP. PROBS. 219 (A utumn 1998) [hereinafter A B A R esolution].

36. I conducted in-person interviews with 40 death penalty lawyers in 10 states between 1993 and 1995 (notes on file with author).

37. Parts of the following section are taken from Sarat, supra note 34 ( $\odot 1997$ The J ohns H opkins U niversity Press; used with permission).

38. Callins v. Collins, 510 U.S. 1141, 1145 (1994) (Blackmun, J ., dissenting from denial of certiorari to Callins v. Collins, 998 F.2d 269 (5th Cir. 1993)). 
colleagues in what he labeled the "legislative" act of finding execution, as then administered, cruel and unusual punishment. ${ }^{39}$ Four years after Furman, he joined the majority in G regg v. G eorgia, deciding to reinstate the death penalty in the U nited States. ${ }^{40}$ However, by the time of his abolitionist conversion, Blackmun had left a trail of judicial opinions moving gradually, but inexorably, away from this early embrace of death as a constitutionally legitimate punishment. ${ }^{41}$ A s a result, his 1994 denunciation of capital punishment was as categorical as it was vivid- "I will no longer tinker with the machinery of death." It was most significant as a factor in the transformation of abolitionist politics, as an example of abolition as legal conservatism, and as an indicator of the anxiety that abolitionists seek to cultivate in the face of the increased popularity of the most dramatic instance of law's violence.

In the U nited States, opposition to the death penalty traditionally has been expressed in several guises. Some have opposed the death penalty in the name of the sanctity of life. ${ }^{42} \mathrm{E}$ ven the most heinous criminals, so this argument goes, are entitled to be treated with dignity. ${ }^{43}$ In this view, there is nothing that anyone can do to forfeit their "right to have rights." ${ }^{44}$ O thers have emphasized the moral horror, the "evil" of the state willfully taking the lives of any of its citizens. $^{45}$ Still others believe that death as a punishment is always cruel and, as such, is incompatible with the E ighth A mendment's prohibition of cruel and unusual punishment. ${ }^{46}$

E ach of these arguments has been associated with, and is an expression of, humanist liberalism or political radicalism. E ach represents a frontal assault on the simple and appealing retributivist rationale for capital punishment. ${ }^{47} \mathrm{E}$ ach puts the opponents of the death penalty on the side of society's most despised and notorious criminals; to be against the death penalty one has had to defend the life of Sirhan Sirhan, J ohn G acey, Timothy M CV eigh, cop killers, and child murderers. Thus it is not surprising that while traditional abolitionist arguments have been raised repeatedly in philosophical commentary, political debate, and legal cases, none has ever carried the day in the debate about capital punishment in the U nited States. ${ }^{48}$ By the time B lackmun wrote his 1994 opinion, it looked like none ever would.

\footnotetext{
39. 408 U .S. 238, 410 (1972) (B lackmun, J ., dissenting).

40. 428 U .S. 153 (1976).

41. See J effrey B. King, Now Turn to the L eft: The Changing I deology of J ustice Harry A. B lackmun, 33 H OUS. L. REV. 277, 297 (1996); see also R andall Coyne, M arking the Progress of a H umane J ustice: H arry Blackmun's D eath Penalty E piphany, 43 U . K A N. L. REV. 367 (1995).

42. SeeA lbert Camus \& A RThur Koestler, RefLections on the Guillotine 169 (1958).

43. See hugo Adam Bedau, Death Is Different: Studies in the Morality, Law, and POLITICS OF CAPITA L PUNISHMENT 16 (1987).

44. Furman, 408 U.S. at 290 (B rennan, J ., concurring).

45. See George Kateb, The Inner O CeAn: Individua lism a nd Democratic Culture 191-

46. See BEDAU, supra note 43 , at $92-128$.

47. For one example of the retributivist rationale, see generally WALTER BERNS, FOR CAPITAL Punishment: CRIME AND the Morality of the DeAth Penalty (1979).

48. See ZIMRING \& HAWKINS, supra note 5, at 148.
} 92 (1992). 
Blackmun's abolitionism found its locus in neither liberal humanism nor radicalism, nor in the defense of the most indefensible among us. It was, instead, firmly rooted in the mainstream legal values of due process and equal protection. Blackmun did not reject the death penalty because of its violence, argue against its appropriateness as a response to heinous criminals, or criticize its futility as a tool in the war against crime. Instead, he shifted the rhetorical grounds.

$\mathrm{H}$ arkening back to Furman, as if rewriting his opinion in that case, B lackmun focused on the procedures through which death sentences were decided: ${ }^{49}$

[D ]espite the efforts of the [s]tates and the courts to devise legal formulas and procedural rules... the death penalty remains fraught with arbitrariness, discrimination, caprice, and mistake.... Experience has taught us that the constitutional goal of eliminating arbitrariness and discrimination from the administration of death ... can never be achieved without compromising an equally essential component of fundamental fairness-individualized sentencing. ${ }^{50}$

T wo things stand out in Blackmun's argument. First, he acknowledges law's effort to purge death sentences of any taint of procedural irregularity. A s he sees it, the main implication of Furman is that a death penalty is constitutional only if it can be administered in a manner compatible with the guarantees of due process and equal protection. Here Blackmun moves the debate away from the question of whether capital punishment is cruel or whether it can be reconciled with society's evolving standards of decency. Second, he identifies a constitutional conundrum in which consistency and individualization-the twin commands of the Supreme Court's post-Furman death penalty jurisprudencecould not be achieved simultaneously. A s a result, Blackmun concludes that "the death penalty cannot be administered in accord with our Constitution." ${ }^{51}$ Blackmun's language is unequivocal; after more than twenty years of effort, Blackmun says, in essence, "enough is enough."

The new abolitionism that Blackmun championed presents itself as a reluctant abolitionism, one rooted in an acknowledgment of the damage that capital punishment does to central legal values and to the legitimacy of the law itself. It finds its home in an embrace, not a critique, of those values. Those who love the law, in Blackmun's view, must hate the death penalty for the damage it does to the object of that love. "R ather than continue to coddle the Court's delusion that the desired level of fairness has been achieved," Blackmun stated, "I feel morally and intellectually obligated simply to concede that the death penalty experiment has failed. It is virtually self-evident to me now that no combination of procedural rules or substantive regulations ever can save the death penalty from its inherent constitutional deficiencies." ${ }^{52}$ In this admonition, we again see Blackmun's categorical conclusion that nothing can "save"

49. See Carol S. Steiker \& J ordan M. Steiker, Sober Second Thoughts: R eflections on T wo D ecades of Constitutional Regulation of Capital P unishment, 109 H A R V. L. R EV. 355 (1995).

50. Callins v. Collins, 510 U .S. 1141, 1144 (Blackmun, J ., dissenting).

51. Id. at 1157.

52. Id. at 1145. 
capital punishment, a conclusion spoken both from within history, as a report of the result of an "experiment," but also from an A rchimedean point, in which the failure of the death penalty is "self-evident" and permanent.

Blackmun's brand of abolitionism describes an important contemporary avenue for engagement in the political struggle against capital punishment, providing abolitionists a position of political respectability while simultaneously allowing them to change the subject from the legitimacy of execution to the imperatives of due process. Blackmun's rhetoric enables opponents of capital punishment to respond to the overwhelming political consensus in favor of death as a punishment; ${ }^{53}$ they no longer have to take on that consensus frontally. They can say that the most important issue in the debate about capital punishment is one of fairness and not one of sympathy for murderers; they can position themselves as defenders of law itself, as legal conservatives. O ne could, new abolitionists now were able to concede, believe in the retributive- or deterrence-based rationalizations for the death penalty and yet still be against the death penalty; one could be as tough on crime as the next person yet still reject capital punishment. A II that is required to generate opposition to execution is a commitment to the view that law's violence should be different from violence outside the law, as well as a belief that that difference could or should be rooted in the fairness and rationality of the violence that law does.

III

\section{VOICESFROM THE BATTLEFIELD ${ }^{54}$}

B lackmun was not alone in articulating a new basis for abolitionist politics. $\mathrm{H}$ is 1994 opinion was significant less as a new development and more as an expression of sentiment already well articulated by a small group of lawyers who specialize in representing persons condemned to death in appellate and postconviction procedures. ${ }^{55}$ Through their lawyering, they seek to prevent executions and, at the same time, end capital punishment. In their practice, they

53. For a description of this consensus, see Phoebe Ellsworth \& Samuel Gross, Hardening of A ttitudes; A mericans' V iews on the D eath Penalty, $50 \mathrm{~J}$. So C. ISSU Es 48 (1994).

54. Some of the material in this section is taken from A ustin Sarat, Between (The Presence of) Violence and (The Possibility of) J ustice: L awyering A gainst Capital Punishment, in CAUSE LAWYering: Political COMmitments and Professional Responsibilities 317 (A ustin Sarat \& Stuart Scheingold eds., 1998) (used with permission).

55. It is impossible to give a precise estimate of the number of people who comprise the "death penalty bar" in the U nited States. H owever, practitioners estimate that number to be about 200 lawyers. A pproximately that number regularly attend the annual A irlie Capital Punishment Conference sponsored by the NAACP Legal Defense Fund. Those who do appellate and post-conviction work practice in a variety of settings; some work for public interest organizations like the Southern Center for H uman R ights, the M innesota A dvocates for Human R ights, the A merican Civil Liberties U nion, or the NAACP L egal D efense Fund. Some are in private practice, and some are in agencies (for example, Federal $D$ efenders $O$ ffices) funded by state or federal government for the purpose of providing representation to persons sentenced to death. 
have daily contact with state violence; they use legal processes in an effort to stop that violence. ${ }^{56}$

Death penalty lawyers, those who are indeed engaged in an ideologically motivated campaign against capital punishment, find themselves fighting for what increasingly looks like a losing cause. ${ }^{57}$ W hile they have the advantage of being able to invoke the formal rights and protections of liberal-legalism, the legal system, as I have already noted, seems ever more inhospitable to them and their work. ${ }^{58}$ To oppose the death penalty through the legal process in the $U$ nited States in the 1990s is not unlike fighting against apartheid in the courts of South A frica in the 1970s, or litigating on behalf of Palestinian rights in the occupied territories in the $1980 \mathrm{~s}^{59}$ In the face of a legal system ever more complicit in the state's effort to impose violence, one might then ask how they have adapted their lawyering activities to the prevailing hostile legal climate. O ne way in which they have done so is to turn from the old, humanist abolitionism to the new abolitionism.

The new abolitionism found among anti-death penalty lawyers is rooted in procedural rather than substantive claims and in the discourse of law rather than of morality. It expresses itself as a form of legal conservatism. The death penalty is rejected, not because of its violent and dehumanizing qualities or for what it says about the relationship of citizens to their government, but because of its corrupting and corrosive effects on the legal system and because it undermines the fundamental legal values of due process and equal treatment. In explaining the strategic orientation of her legal work, one of the new abolitionists said,

I'm frustrated because I'm not a great liberal. In fact, in many ways I'm pretty conservative. But I believe that if we are going to truly have a system of law, law has to operate in a way that ensures fundamental fairness, and that is what we don't have in the death penalty. If they try to seek it against the wealthy, they don't get it because

56. D espite the importance of what they do, their work has been almost invisible to the scholarly community. In outlining an agenda for future research in the area of capital punishment, Franklin Zimring described the significance of what he called "the capital punishment bar." See Franklin E . Zimring, O n the L iberating V irtues of Irrelevance, 27 L. \& SOC'Y REV. 9, 15 (1993). Zimring suggested that "the litigation of death penalty issues has produced in some states a group of appeals lawyers who are a full-time capital punishment bar." Id. He called on scholars to investigate how "attorneys in this sort of practice define their roles and ... their attitudes toward the legitimacy of the criminal justice system. This study is the most immediately interesting, but not the only, research undertaking that would investigate the role of capital punishment as an influence on the legal profession." Id. For studies of the death penalty bar, see MELTSNER, supra note 4; James M. D oyle, The L awyers' Art: "Representation" in Capital Cases, 8 Y A LE J . L. \& H U M A N. 417 (1996); A ustin Sarat, B earing Witness and Writing History in the Struggle A gainst Capital Punishment, 8 Y A LE J. L. \& H U M A N. 451 (1996); Sarat, supra note 54; A ustin Sarat, Narrative Strategy and Death Penalty Advocacy, 31 HARV. C.R .C.L. L. REV. 353 (1996); E ric L. Muller, N ote, The L egal D efense Fund's Capital Punishment Campaign: The D istorting Influence of D eath, 4 Y A LE L. \& POL'Y REV. 158 (1985).

57. See L ouis D. Bilionis, L egitimating D eath, 91 M ICH . L. REV. 1643 (1993).

58. See W eisberg, supra note 14.

59. See Richard A bel, Speaking Law to Power: Occasions for Cause L awyering, in CAUSE LA WYERING, supra note 54, at 69; see also R onen Shamir, Litigation as a Consummatory Action: The Instrumental Paradigm Reconsidered, 11 STUD. L. POL. \& SO C'Y 41 (1991). A s Shamir argues, even in conditions of oppression, petitioners turn to courts because they "are able, for the first time, to express their grievances and to materialize their appeal for grace and abstract justice." Id. at 61. 
they get good lawyers who do the work and juries don't return it. But they can do what they want to minorities. In that situation, I have to use my skills to level the playing field. For me that is why I do it, to level the playing field. I can't do it in very many cases, but here I can do a bit to make it more level. ${ }^{60}$

Or, as another explained,

When I first thought about doing death penalty work I had very complicated views about the death penalty. I was agnostic on the underlying philosophical issues. I didn't, and don't, think of myself as an abolitionist. When I hear the A mnesty International people talk, I want to be distant from them because they speak in hyperbole. B ut when I started, I talked to people who said that you didn't have to be an abolitionist in the classic sense because the application of the system is so unfair that your interest should just be on fairness. I have come to think that it is inappropriate for the state to be executing individuals with very few exceptions. I think that it's probably appropriate to execute people who commit crimes like high treason. However, my current view is that we should stop it. Y ou can never get to the theoretical debate because the system we actually have is so far from perfect. If we had a perfect system, then we could think about the theoretical issue. But in fact we don't have anywhere near close to such a system. We are executing people just because they have crappy lawyers who do crappy jobs at trial. A nd the actual application of the death penalty is a travesty. So my views are primarily in opposition to the system that we have as well as any system I can imagine in the near future.

The new abolitionism focuses attention on the daily realities of administering state violence and refuses to engage more abstract, theoretical concerns. For some in the death penalty bar, this position is connected to a more farreaching narrative of violence and justice in which race plays an especially pivotal role. For them, death penalty work is part of a broad-based political struggle for civil rights and political equality. The cause for which these lawyers are fighting is only incidentally to stop executions; they are dedicated to using law in a battle for equality and decent treatment for all persons. The narrative of injustice which they construct in their work is "structural" and "systemic" rather than "legalistic," ${ }^{61}$ and the effort to stop executions is valuable insofar as it provides a strategic vehicle for addressing larger and more encompassing social issues. A s one young lawyer said,

I think the litigation of death penalty issues in the criminal justice system in the 1990s is what civil rights litigation was in the ' 50 s and ' $60 \mathrm{~s}$. Y ou are dealing with a group of people who are in this situation not so much because of what they did, but because of who they are. A nd who they are has a lot to do with the color of their skin and their socio-economic status.

A nother lawyer described his death penalty work as "the civil rights work of our era." He noted that

there are established remedies for discrimination in other areas, whether education or employment, there is a way to remedy it that uses the courts. Whereas in our area, anyone who does this work knows that racism is one of the most important influences

60. My interviews lasted from one to three hours. Transcripts are on file with the author. In order to protect the confidentiality of my respondents, I provide minimal descriptive information about them.

61. For a discussion of these distinctions, see Robert Gordon, Undoing H istorical Injustice, in J USTICE AND INJUSTICE IN LAW AND LEGA L THEORY 36-39 (A ustin Sarat \& Thomas R. Kearns eds., 1996). 
in deciding who gets the death penalty and who doesn't, who's prosecuted for capital murder and who's not. A nd yet a real remedy doesn't exist.

$Y$ et the prevalence of such a broad-based political critique among some death penalty lawyers should not be taken to suggest that radical political commitment overcomes legal conservatism in this community. A s a woman in private practice explained, "I'm a mixed bag. I'm not like a knee-jerk liberal. I'm fiscally pretty conservative. I live out in the suburbs, a very conventional lifestyle. I have a little girl. I'm married. I guess I would say I'm a moderate." Still others, while distancing themselves from the abolitionist label, note the importance of a deep commitment to the struggle against capital punishment. A s one lawyer explained,

I guess people could say, "W ell, I'm not an abolitionist and I think that there is someone out there who should get it" and still be driven by a certainty about their client's case. But I doubt it. Those people are not driven at the same level if they don't believe that this is more than just a job, and it is about more than just one client. They're going to avoid connecting with them as human beings because of a desire not to have it intrude on their lives. If there is a mob out there that wants to kill your guy, you are going to have to stop it singlehandedly and that means making some pretty serious exertions. A t that point, you better not be thinking, "This is just a job." It better be a real important cause for you or you just won't do it.

Death penalty work is, on this account, "more than just a job," and it requires a commitment to "more than just one client." For this lawyer, political commitment can and should be expressed through client representation. It need not be a barrier to effective client advocacy. In fact, such commitment seems to be essential if a death penalty lawyer is going to "connect" with the person he represents. Connecting with the client at a human level, when everywhere he is regarded as sub-human because of what he has done, is a crucial component of the political work of death penalty lawyers.

It should not be surprising that even in the face of the importance of the new abolitionism for anti-death penalty lawyers, some continue to speak of traditional abolitionism in which the death penalty is rejected as an immoral act. For them, the immorality of the death penalty is founded on a belief in the incompatibility of capital punishment on the one hand and the values of a civilized society on the other. ${ }^{62}$ A s a result, they seek to use their lawyering skills to stop at least this one aspect of state violence, though even for most of them traditional abolitionist rhetoric co-exists with new abolitionist strategy. O ne such abolitionist lawyer told me that

I do this work because I'm opposed to the death penalty. I'm an abolitionist. I have responsibilities to individual clients, and those obviously override everything. But to me this is an ideological struggle. I do this work as an extension of my beliefs. We are going to take this person in and kill him. I think deciding to kill someone as a society is a decision that reveals society's corruption.

62. See H ugo A dam Bedau, The Eighth A mendment, H uman Dignity, and the Death Penalty, in The CONSTITUTION Of RIghtS: HuMAN DIGNITY AND A MERICAN VA LUES 145, 148 (M ichael Meyer \& William Parent eds., 1992). 
For many death penalty lawyers, the "ideological struggle" is animated by a deep opposition to violence. This opposition is revealed in the comment of a young woman who worked for several years in a D eath Penalty R esource Center:

I oppose capital punishment for a multitude of reasons, but mostly from a moral perspective. I don't think that the government should kill its citizens. It is a far more natural impulse to keep people alive than to kill them. A nd in my view government is a parent figure. The same reason I don't hit my daughter is why the government should not kill my clients. If the government responds in a violent way to the problem of violence, it is, whatever its intention, sending the message that violence is okay.

G overnment as "parent" domesticates and familiarizes the debate about the death penalty. ${ }^{63}$ It suggests that the question of the death penalty has to be seen not just in terms of the usual discussion of crime and retribution, but in terms of its "radiating effects" in the larger society.

"The death penalty is wrong," another lawyer said, echoing this concern for its radiating effects, "because it denigrates humanness. The government shouldn't be in the killing business. It minimizes human life in the sense that you are saying the government is superior and more important than individual human lives." 64

$Y$ et it is precisely these arguments that have little or no political resonance today. The only avenue that seems even remotely open is to follow B lackmun and seek to revive the spirit of Furman by claiming that the death penalty has not been, and cannot be, administered fairly and even-handedly. For antideath penalty lawyers, telling stories of racism, poverty, and family dysfunction and showing how these things play out in the capital sentencing process endows their work with political meaning even as it raises the question of whether doing death penalty work is the most strategically sound manner of addressing social justice issues. ${ }^{65}$ This is an especially pressing question given what most death penalty lawyers acknowledge is the very hostile political and legal climate for their work.

This recognition is captured by a lawyer who said, in a classic understatement, "W e are not living in a very good climate for death cases. There might not ever be one, but today is certainly not a good one." A nother lawyer made the same point by highlighting a change from the days when she first started to represent people on death row to the present moment:

63. The idea of government as "parent" is reminiscent of Justice Brandeis's belief that "[0]ur [g]overnment is the potent, omnipresent teacher." OImstead v. U nited States, 277 U .S. 438, 485 (1928) (B randeis, J ., dissenting).

64. A s K ateb argues,

the institution of capital punishment strengthens the sentiment that the state owns the lives of the people. Many things can be said against capital punishment, but one of the most relevant... is that the state's power deliberately to destroy innocuous (though guilty) life is a manifestation of the hidden wish that the state be allowed to do anything it pleases with life.

K A TEB, supra note 45, at 191-92.

65. For a general treatment of this issue, see M ichael McCann \& Helena Silverstein, R ethinking $L$ aw's "Allurements": A Relational A nalysis of Social Movement Lawyers in the United States, in CAUSE LAWYERING, supra note 54, at 261. 
When I started there was still so much hope. Today the train is on the way down the track and everyone is jumping off, and we are here as the last hope. But now the cases are so miserable because of what the courts have done. The Supreme Court has continued to put up barriers in our way. A nd every time they point you down one road you go down that road and then they say, "W e were just kidding. We don't allow you down here any more." So things have changed. It's an injustice what has happened, an absolute injustice.

This description of a movement from hope to an "absolute injustice" perpetrated by courts that are fully attentive and attuned to a belligerent, pro-death penalty political constituency depends on what Robert Gordon called an "agency-based" narrative. ${ }^{66}$ A similar narrative was invoked by a veteran death penalty lawyer who claimed, "We were beating them at every turn, so long as they were taking due process seriously. Then they could never get past us. So they just changed the rules." Such a change occurred, he explained, because

the pro-death penalty temperature is rising quite a bit. State legislators just foam at the mouth to see people executed. State courts are becoming much more angry and impatient with anything we say or do. A ttorneys G eneral are more organized in trying to prod and goad the courts into that kind of impatience. There is a real fight that we've been losing for the past seven or eight years about whether there is going to be even any pretense to real due process. The system is full of displaced aggression directed against us and the people we represent. A nd now there is a real capital punishment bureaucracy, maybe 10,000 people across the country. It's under pressure from people who are setting the budget to just move people along toward execution.

For this lawyer, the difficulty of successfully opposing capital punishment has been compounded by the creation of a death penalty bureaucracy with its own vested interests and desire for political survival. ${ }^{67}$

In an environment in which "the pro-death penalty temperature is rising quite a bit," courts, once sympathetic to the claims of opponents of the death penalty, now no longer even "listen." "Y ou are continually working hard," one lawyer said, "to dig up new facts and identify good issues that will make them face the horrors of the death penalty, but the most frustrating thing is when you present it to a court that just doesn't care." In the words of one of her colleagues who practices in a public interest setting,

I really do think that there is a deep sense in the community opposed to capital punishment that nobody listens. Y ou can file something that's really long, but it doesn't matter [because] they [judges and legislators] aren't even going to read it. A nd if it is read, it is read with an eye to figuring out how to deny what you are saying.

The question for the death penalty bar, as one practitioner put it,

is not figuring out a strategy for how you are going to win. If you do this work, you quickly shed that illusion. The death penalty is here to stay, at least in our lifetimes. The question is almost always now "how do you want to lose," and "where do you want to lose," not "how do you win?" Victory is minimizing the losses you take in certain places. Y ou want to sneak by in the middle of the night, as it were, and be denied quietly without any sort of drawing undue attention to what may be your meritorious claims in the long, long run. It really is a question of knowing that you are going

66. Gordon, supra note 61 , at 36. A n agency-based narrative frames injustice as "wrongs done by specific perpetrators to specific victims." Id.

67. For an interesting study of one part of this bureaucracy, see ROBERT JOHNSON, DEATH WORK: A STUdY OF THE MODERN EXECUTION PROCESS (1990). 
to lose. It's knowing what do you want to do in the act of losing. It's the last word syndrome, "R ight before you die, do you have any last words?"

B ecause proponents of capital punishment have such a stronghold on public opinion and are so firmly entrenched in the political process, death penalty lawyers generally accept that "the death penalty is here to stay" and that victory consists in "minimizing losses." For many, death penalty work has now become "like working with the terminally ill. Y ou know that the cure rates are pretty low. So you cure the very few that you can and those many who you can't cure you make their lives comfortable and fight to keep them alive as long as possible."

The perception that the courts are no longer listening to anti-death penalty arguments and that the best one can hope for is to keep one's clients alive "as long as possible" is further compounded by the sense that other kinds of political opposition to capital punishment are also futile. A s one practitioner characterized it,

I'm a member of all the abolitionist groups, and we are clearly their major source of information. But the truth is that I think that they are so unrealistic. They are so far from where public opinion is these days. I guess it is not surprising that one of the things that I don't like about this job is how ineffectual we are so many times. I don't want to be next to the people who are holding the banners when there are six of them holding their little candles outside when someone inside is being executed, and the state is voting eighty-five percent for the death penalty. We get so hammered in public, by the press, and by the establishment that the bunker mentality is now really pretty pervasive. ${ }^{68}$

It is in this climate that abolitionism has turned conservative, motivated by the sense that the best hope of ending capital punishment lies in an effort to recapture the spirit of Furman, an effort for which those in the anti-death penalty movement must adopt a long time horizon.

Those fighting the death penalty today must take seriously Drucilla Cornell's admonition that "legal interpretation demands that we remember the future." ${ }^{69}$ In that phrase, Cornell suggests that law fixes its gaze temporally, not on the possibilities (or impossibilities) of the present, but on a future promise of justice. She reminds us that there are, in fact, two audiences for every legal act, the audience of the present, which, as in the case of the death penalty, might be unresponsive, and the audience of the future, to which arguments

68. This sense of disconnection between the political and legal arms of the movement to end the death penalty was widespread among the lawyers with whom I spoke. A s one put it, "I don't have the faintest idea what one could do from the point of view of a lay person trying to do political action on the death penalty at this point. If there is an abolitionist movement left in this country, it is largely composed of people like me doing legal work." Or, as another said, "I think of the lawyers who do death penalty stuff as the foot soldiers of the movement. We are the activist arm because a group of people holding candles outside the Governor's mansion are not going to end capital punishment." Still another expressed this same sentiment by saying, "It's hard for me to go to these meetings of dogooders who are all beating their chests and upset about the death penalty. It is just a huge waste of time. It's nothing. I'd rather blow up the courthouse than sit around and whine about how bad things have gotten."

69. D rucilla Cornell, From the $L$ ighthouse: The Promise of R edemption and the Possibility of $L$ egal Interpretation, 11 CARD OZO L. REV. 1687, 1709 (1990). 
nonetheless might be addressed. In this sense, law, as R obert Cover writes, is a bridge to "alternity." 70

In Cornell's and Cover's understanding, the popularity of the new abolitionism among anti-death penalty lawyers might be seen as a form of what Cover called "redemptive constitutionalism." ${ }^{71}$ Through their arguments about fairness and equality, those lawyers call on A mericans to live up to their most cherished ideals. They refuse to recognize the violence of the present moment as the defining totality of law. For them, as Cover argues, "R edemption takes place within an eschatalogical schema that postulates: (1) the unredeemed character of reality as we know it, (2) the fundamentally different reality that should take its place, and (3) the replacement of one with the other."72

Cover uses the example of an abolitionist struggle of another era, namely anti-slavery activism in the mid-nineteenth century, to suggest that the work of "redemptive constitutionalism" reveals "a creative pulse that proliferates principle and precept, commentary and justification, even in the face of a state legal order less likely to hold slavery unconstitutional than to declare the imminent kingship of J esus Christ on Earth." ${ }^{73}$ In this view, the abolitionist lawyer supplies the argumentative and interpretive resources to bridge the gap between the present political climate and a possible future realization of our legal ideals.

But there is perhaps a second way of understanding the utility of the new abolitionism in the work of anti-death penalty lawyers. In this second understanding, Cover's image is reversed, and redemption gives way to judgment, and as this occurs, the future is called on to remember the injustices of the present. $^{74} \mathrm{G}$ iven this imperative to remember, those lawyers provide

the testimonial bridge which, mediating between narrative and history, guarantees their correspondence and adherence to each other. This bridging between narrative and history is possible since the narrator is both an informed and an honest witness.... A Il the witness has to do is to efface himself, and let the literality of events voice its own self-evidence. "H is business is only to say: this is what happened, when he knows that it actually did happen." 75

A rguments about present day violations of due process and equal protection in the administration of capital punishment help to write a history of shame. These arguments record the failure of law to restrain the political im-

70. See R obert M. Cover, The Supreme Court, 1982 Term-Foreword: Nomos and Narrative, 97 HARV. L. REV. 4, 9 (1983).

71. Id. at 34 .

72. Id.

73. Id. at 39 .

74. For a discussion of the way we think about the future, see J A CQUES LE G OFF, HISTORY AND MEMORY 11 (Steven R endall \& E lizabeth Claman trans., 1992).

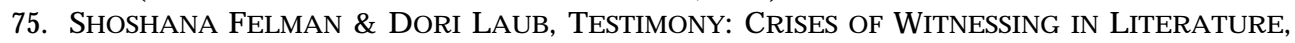
PSY CHOA NA LYSIS, A ND H ISTORY 101 (1992). Treating anti-death penalty lawyers as witnesses giving testimony suggests that they are addressing their work to the community of the future as much as the law of the present. "To testify before a court of law or before the court of history and of the future," as Felman argues, "is more than simply to report a fact or an event or to relate what has been lived, recorded and remembered. Memory is conjured here essentially in order to address another, to impress upon a listener, to appeal to a community." Id. at 204. 
pulses of the moment. They enable anti-death penalty lawyers to create a record, to turn legal institutions into museums of unnecessary, unjust, undeserved pain and death, of law's failure to honor its most basic and important commitments in a context where lives are on the line. ${ }^{76}$

The commitment of abolitionist lawyers to speak to the future and memorialize law's present failures has been ignored by those who have worried too much about the impact of such lawyering on the political possibilities of the present. $^{77}$ B ut, as Cornell reminds us, legal struggle is as much about the future as the present, and as much about the possibilities of keeping alive commitments as the current prospects of political success. Thus, when anti-death penalty lawyers deploy the vocabulary of the new abolitionism, they

posit the very ideal [they] purportedly find "there" in the legal text, and as [they] posit the ideal or the ethical [they] promise to remain true to it. [Their] promise of fidelity to the ethical or to the ideal is precisely what breathes life into the dead letter of the law and provides a barrier against the violence of the word.... To heed the call to responsibility within law is both to remind [ourselves] of the disjuncture between law and the ideal and to affirm our responsibility to make the promise to the ideal, to aspire to counter the violence of our world in the name of universal justice. ${ }^{78}$

This component of the work of death penalty lawyers is referred to, within that community, as "making a record." By "making a record," death penalty lawyers do not just describe the legal work of building a case on appeal. In addition, they refer to the broader work of witnessing and writing history. By making a record, these lawyers surmount, if they cannot stop, the violence of law's present and keep alive the possibility of a more just future. They remember the future and insist that the future, if it is to be more just, must remember.

"L ook, as a lawyer, every single act or omission that I am doing is calculated to make a record," one experienced lawyer explained,

but not just the record on appeal. It is bigger than that. I think you are making a record above and beyond the immediate case. Y ou are making a record that even after you ultimately fail to save your client's life that he was a worthy human being, that there was an explanation for what he did which the legal system could not, or would not, hear. I know that because I know him in ways no one else does. A nd that there are other young men and women out there who can be helped if we learn from this case. Y ou see what we do is we tell a story that would otherwise not be told, or remembered. There are lessons in the stories we tell, lessons about poverty, abuse, and injustice. M aybe they can't be heard just yet, but maybe they will be heard sometime.

This lawyer first speaks as a witness, whose work testifies to the humanity of those condemned to die. Here, he speaks as someone who has first-hand knowledge. "I know that," he says, "because I know him in ways no one else does." B ut this lawyer also insists that his work is "bigger than that." "M aking

76. A s M inow suggests, legal rights matter not just because they provide dignity to law's victims, or because they help to mobilize them to undertake political action, but because they provide an opportunity to tell a story that might not otherwise get to be told. See Martha M inow, Interpreting Rights: A n E ssay for Robert Cover, 96 Y A LE L.J. 1860, 1876-77 (1987).

77. See McCann \& Silverstein, supra note 65, at 261; see also StUART A. SCHEIngold, The Politics of Rights: LA WYERS, PUbliC Policy, and PolitiCal Change (1974).

78. D rucilla Cornell, Post-Structuralism, the Ethical Relation, and the Law, 9 CARDOzo L. REV. 1587, 1628 (1988). 
a record" involves recording the history of the present in which an instance of injustice to which he can testify is generalized and put into a narrative that ties his case to a larger picture of "poverty, abuse, and injustice," and the failure of law's promise of equal protection. The process of generalization involves telling a story about "other young men and women out there." Such a story addresses the future which may (and should) remember, but whose recollection can be spoken about only as the possibility of an indeterminate "sometime."

In spite of such uncertainty, the belief in the importance of making a record remains pervasive. A s one lawyer said,

I think of what I do as sort of making a narrative. I'm telling a story with page after page of facts which are put together to show the richness and complexity of my client's life, of the crime, and of the injustices of his trial. I am trying to put it together in a way that people can understand, that pulls heartstrings by getting at what is really going on. This is the best way to win in court, and it is the best way to make sure that the story is not just pushed aside and forgotten. A nd if enough of these narratives get produced, then maybe they won't be ignored when, say fifty years from now, people try to figure out why we were executing the people we were executing in the way we were doing it.

M aking such a record, this lawyer explained,

is our way of acting in the world, our way of struggling against the system. We create these papers that we write. They are not going anywhere. They will be in government document warehouses forever. A nd I think that someday somebody will look at this, maybe 100 years from now, but someone will look and say "Oh my God, it was true that the death penalty was really just an engine of discrimination." Even if it seems fruitless now, it is worth doing because we are making a record of who is getting the death penalty, and it was just the people who were mentally ill and too poor for treatment who came from unhappy, broken families. A nd we did nothing to help these people, until they did something horrible so we could then get rid of them. [T] his is not just my perception... . I've talked with enough other people to describe this work as a witnessing sort of function.

What seems "fruitless" today takes on meaning when viewed in the long term. A society now unwilling to see the linkages between poverty, neglect, and the death penalty, may " 100 years from now" be more receptive. Lawyering against the death penalty thus seems like trying to put a crucial piece of evidence in a time-capsule. A nti-death penalty lawyers do not just say what happened, they construct explanations that will focus the future's attention on law's failures as well as mental illness and poverty, on social neglect, and on the unforgivable desire to "get rid of" people with problems rather than trying to fix those problems. The new abolitionism hopes to speak to a broad range of people of diverse political perspectives as it tries to educate them about what today's death penalty is doing to our most enduring legal values.

The new abolitionism is based on what I would call a "democratic optimism," a belief that present support for the death penalty is rooted in ignorance rather than venality, misunderstanding rather than clear-headed commitment. Here, people in the anti-death penalty movement take instruction from the late J ustice Thurgood M arshall, who, when confronted with evidence of widespread public endorsement of capital punishment, argued that 
whether a punishment is cruel and unusual depends, not on whether its mere mention "shocks the conscience and sense of justice of the people," but on whether people who were fully informed as to the purposes of the penalty and its liabilities would find the penalty shocking, unjust, and unacceptable. ${ }^{79}$

If they were given such information, $M$ arshall believed, "the great mass of citizens would conclude ... that the death penalty is immoral and therefore unconstitutional. ${ }^{180}$

Some death penalty lawyers argue, following $\mathrm{M}$ arshall, that if they hold to the strategy of the new abolitionism, they indeed will produce such a predictable result. A s one woman earnestly explained, "I do not think that the death penalty will exist $X$ years from now. While I don't know what $X$ is, I think at some point people are going to look back and think 'H oly, moley, look at what was going on back then.'" "Look at Blackmun," another lawyer said. "He is not so very different from the rest of the country. $\mathrm{H}$ is evolution is very representative of what eventually this country will come to if we continue to do our work. We have to look a little longer down the road, beyond the present moment." A third lawyer was even more explicit in his democratic optimism:

\begin{abstract}
I believe that the people of this state, and others, are good people. Their support for the death penalty is sustained through a set of interconnected beliefs none of which is true. They believe that the legal system is not racist. A nd if you could get them to see that the system picks out black people and sends them to the chair, they would say, "That's not fair." They believe that in some objective sense the worst offenders get the death penalty, that death row is full of Charles M ansons who killed more than one person and who are really super morally culpable. I think if they were told, like we are telling everyday, that there are a lot of young kids on the row who were stoned out of their minds or it isn't even clear if they pulled the trigger, it would matter. A nd they believe that everybody gets adequate representation. But if they knew how abysmally poor a lot of the legal representation is, they would be appalled. This is what we see and what we are trying to document. We are creating a database that is necessary for any political movement to build on. We are putting together the records through which people will one day learn the truth about capital punishment.
\end{abstract}

Sentiments like these connect law to the future and establish a different understanding of the work of anti-death penalty lawyers. They go back to the future by trying to revive the sprit of Furman; they give law a life in and through time. Those sentiments help explain the political dimensions of lawyering that appears legally conservative in its appeal to due process and equal protection rather than to more transformative visions of society, and seems entirely focused on the particularities of a single case.

IV

\title{
RIDING TO THE RESCUE:The A MERICAN BAR A SSOCIATION AND THE LEGITIMATION OF THE NEW A BOLITIONISM
}

In spite of its legally conservative character and appeal to mainstream legal values, those advocating the new abolitionism have been caught in a political crossfire, accused of frustrating the popular will by being hyper-legalistic, of

79. Furman v. G eorgia, 408 U .S. 238, 361 (1972) (M arshall, J., concurring).

80. Id. at 363 (M arshall, J ., concurring). 
using and abusing technicalities to keep their clients alive. R ather than being respected as the guardians of important legal values rooted in the Fourteenth A mendment guarantee of due process of law or of equal protection, ${ }^{81}$ antideath penalty lawyers are vilified as rogues who violate the canons of their profession by conducting an ideologically motivated guerilla war against capital punishment. $^{82}$ A s the Supreme Court put it when it refused to grant a stay of execution to R obert A Iton $\mathrm{H}$ arris,

$\mathrm{H}$ arris seeks an equitable remedy. E quity must take into consideration the state's strong interest in proceeding with its judgment and Harris's obvious attempt at manipulation. This claim could have been brought more than a decade ago. There is no good reason for this abusive delay, which has been compounded by last-minute attempts to manipulate the judicial process. ${ }^{84}$

Such language by now is a regular staple of death penalty cases. ${ }^{85}$ A s A nthony A msterdam notes, in a series of cases extending back before the $\mathrm{H}$ arris case and continuing on to today, courts have woven a "conspiracy myth," a myth of lawyers pursuing frivolous legal claims in last-minute petitions. ${ }^{86}$ A s Chief J ustice R ehnquist put it in Sawyer v. Whitley,

In the every day context of capital penalty proceedings, a federal district judge typically will be presented with a successive or abusive habeas petition a few days before, or even on the day of, a scheduled execution.... We of course do not in the least condone, but instead condemn, any efforts on the part of habeas petitioners to delay their filings until the last minute with a view to obtaining a stay because the district court will lack time to give them the necessary consideration before the scheduled execution. ${ }^{87}$

The conspiracy myth, A msterdam contends, gives judges somebody to be angry at, allows them to deny the legal significance of the issues raised by lawyers fighting executions, and to explain why so few executions were being carried out. $^{88}$ It demonizes anti-death penalty lawyers and discredits the new abolitionism, just as the old abolitionism had been discredited for being sympathetic to some of society's most despised persons.

J ust at the moment when one might have been prepared to consign the new abolitionism to the same fate as other forms of abolitionist politics and, in so

81. This image is developed by $M$ ichael $M$ ello, Facing $D$ eath Alone: The Post-Conviction A ttorney Crisis on D eath Row, 37 A M. U. L. REV. 513, 606 (1988). A s M ello argues,

The post-conviction process has become an integral part of the system of capital punishment.

The post-conviction component of the system is necessary because it exposes injustices. ... It is necessary to the integrity of a legal system that strives to tame the death penalty within the Id. rule of law. In turn, lawyers are essential to the integrity of the post-conviction process.

82. See N ote, The L egal D efense Fund's Capital Punishment Campaign: The D istorting I nfluence of Death, 4 Y A LE L. \& POL'Y REV. 158 (1985).

83. Harris was the first person executed in California in the post-Furman era.

84. Gomez v. U nited States, 503 U .S. 653, 654 (1992) (citations omitted). For an important response, see Charles M. Sevilla \& M ichael L aurence, Thoughts on the Cause of the Present $D$ iscontents: The D eath Penalty Case of Robert A Iton H arris, 40 U CLA L. REV. 345 (1992).

85. See A msterdam, supra note 11.

86. Id.

87. 505 U .S. $333,341 \&$ n.7 (1992).

88. See A msterdam, supra note 11 , at 36-37. 
doing, to accept that the demand for death now knows no constitutional scrupulousness, an important new voice has entered the fray. ${ }^{89}$ Three years to the month after Blackmun's 1994 dissent in Callins v. Collins, the A merican Bar A ssociation ${ }^{90}$ called for a complete moratorium on executions in the $U$ nited States. $^{91}$ Taking us back to Furman's condemnation of the death penalty as "then administered," the A BA proclaims that the death penalty as "currently administered" is not compatible with the central values of our Constitution. Since Furman, the effort to produce a constitutionally acceptable death penalty has, in the view of the $A B A$, been to no avail. Thus, the $A B A$ "calls upon each jurisdiction that imposes capital punishment not to carry out the death penalty until the jurisdiction implements policies and procedures ... intended to (1) ensure that death penalty cases are administered fairly and impartially, in accordance with due process, and (2) minimize the risk that innocent people may be executed." 92

H owever, the language of the $A B A$ resolution, unlike $B$ lackmun in $C$ allins, seems conditional and contingent in its condemnation of death as a punishment. E ven as it calls for a cessation of executions, it appears to hold out hope for a process of reform in which the death penalty can be brought within constitutionally acceptable norms. A s if to leave little doubt of its intention, the $A B A$ resolution concludes by stating that the $A$ ssociation "takes no position on the death penalty." ${ }^{93}$

The A BA recommendation, whatever its explicit refusal to take a position on the ultimate question of the constitutionality of capital punishment, amounts to a call for the abolition, not merely the cessation, of capital punishment. It does the work of Blackmun's new abolition without his overt and categorical renunciation. If one takes seriously the conclusions of the report accompanying the $A B A$ 's recommendation, then the largest, most conservative association of lawyers in the country is asking A mericans to save further damage to the law by ending the death penalty. In so doing, the A BA provides a striking response to the continuing anxiety that attends law's embrace of the state's ultimate violence. ${ }^{94}$ J ust as rushing a fresh contingent of troops into a

89. The next several pages draw heavily on my article A bolitionism as L egal Conservatism, supra note 34 (@ 1997 The J ohns H opkins U niversity Press; used with permission).

90. On the politics of the ABA, see JEROLD AUERBACH, UNEQUAL JUSTICE: LAWYERS AND SOCIA L CHANGE (1976); R ichard L. A bel, Why D oes the ABA Promulgate Ethical Rules?, 59 TEX. L. REV. 639 (1981).

91. A BA R esolution, supra note 35 , at 1, reprinted in A ppendix, supra note 35, at 219.

92. Id.

93. Id., reprinted in A ppendix, supra note 35, at 220.

94. This anxiety arises because that violence, as both a linguistic and physical phenomenon, as fact and metaphor, is integral to the constitution of the modern state. See A ustin Sarat \& Thomas R. K earns, A J ourney Through Forgetting: Toward a J urisprudence of Violence, in THE FA TE OF LA W 209 (A ustin Sarat \& Thomas R. Kearns eds., 1991). That state is built on representations of aggression, force, and disruption lurking just beyond its boundaries. In large measure, the state seeks to authorize and legitimate its bloodletting as a lesser or necessary evil and as a response to our inability to live a truly free life without external discipline and restraint. $Y$ et the proximity of the state to, and its dependence on, violence raises a nagging question and a persistent doubt about whether it can ever be more than violence or whether the violence law condones is truly different from, and superior to, what 
battle going badly may reinvigorate those grown weary, even if ultimately it does not stem the tide, so too the A B A 's action provides an important response to the courts' conspiracy myths; it provides crucial symbolic capital for the antideath penalty community and legitimation to the new abolitionism.

The ABA report provides three reasons for its call for a moratorium on executions, each a crucial component of the new abolitionism. ${ }^{95}$ The first is the failure of most states to guarantee competent counsel in capital cases. B ecause most states have no regular public defender systems, indigent capital defendants frequently are assigned a lawyer with no interest, or experience, in capital litigation. ${ }^{96}$ The result is often incompetent defense lawyering, lawyering that has become all the more damaging in light of new rules requiring that defenses cannot be raised on appeal or in habeas proceedings if they are not raised, or if they are waived, at trial. ${ }^{97}$ The A BA itself calls for the appointment of "two experienced attorneys at each stage of a capital case." ${ }^{98}$ While, in theory, individual states could provide competent counsel in death cases, and while there is ample evidence to suggest the value of skilled lawyers in preventing the imposition of death sentences, ${ }^{99}$ the political climate in the $U$ nited States as it touches on the crime problem suggests that there is, in fact, little prospect for a widespread embrace of the A B A 's call for competent counsel.

The second basis for the $A B A$ 's recommended moratorium is the recent erosion in post-conviction protections for capital defendants. While the A BA notes that "the federal courts should consider claims that were not properly raised in state court if the reason for the default was counsel's ignorance or neglect and that a prisoner should be permitted to file a second or successive federal petitions if it raises a new claim that undermines confidence in his or her guilt or the appropriateness of the death sentence, ${ }^{100}$ the direction of legal change is, as I already have noted, in the opposite direction. Today courts in the U nited States are prepared to accept that some innocent people, or some defendants who do not deserve death, will be executed. ${ }^{101}$ A s J ustice R ehnquist observed in Herrera v. Collins, "due process does not require that every con-

lurks beyond its boundaries. See J acques $D$ errida, Force of $L$ aw: The "M ystical Foundation of Authority", 11 CA R D OZO L. REV. 921 (1990).

95. The report and recommendation both call for a permanent halt to the execution of juveniles and the mentally retarded.

96. See Stephen B. B right, Counsel for the Poor: The D eath Sentence N ot for the Worst Crime, but for the Worst L awyer, 103 Y A LE L.J . 1835 (1994).

97. See R onald Tabak, Pannel D iscussion: Capital Punishment: Is There A ny $H$ abeas $L$ eft in This Corpus? Commentary, 27 L OY. U . CHI. L.J . 523, 581 (1996) (comments of Scharlette H oldman).

98. A merican Bar A ss'n, R eport No. 107, at 5 (1997), reprinted in A ppendix, supra note 35, at 223 [hereinafter A BA R eport].

99. See A ustin Sarat, Speaking of D eath: Narratives of Violence in Capital Trials, $27 \mathrm{~L}$. \& Soc'Y REV. 19 (1993).

100. A B A R eport, supra note 98, at 10, reprinted in A ppendix, supra note 35, at 227.

101. See Michael L. RAdelet et al., In Spite of InNocence: ERroneous Convictions in CA PITA L CA SES 271 (1992); see also Samuel R. Gross, L ost L ives: M iscarriages of J ustice in Capital Cases, 61 LAW \& ConTEMP. ProBS. 125 (A utumn 1998); M ichael L. R adelet \& H ugo A dam Bedau, The Execution of the Innocent, 61 LA W \& CONTEMP. PR OBS. 105 (A utumn 1998). 
ceivable step be taken, at whatever cost, to eliminate the possibility of convicting an innocent person." 102 A nd for R ehnquist, what is true in the general run of criminal cases is also true in death cases. If a few errors are made, a few innocent lives taken, that is simply the price of a system able to execute anyone at all. In R ehnquist's view, finality in capital cases is more important than an extended, and extremely frustrating, quest for justice. ${ }^{103}$ For him, and others like him, the apparent impotence of law, its inability to turn death sentences into executions, is more threatening to its legitimacy than a few erroneous, undeserved deaths at the hands of the state.

$\mathrm{H}$ ere again, what the ABA asks for, namely a restoration of some of the previously available habeas remedies, is theoretically conceivable. $Y$ et, like efforts to improve the quality of defense counsel in capital cases, it is hardly a likely or near-term possibility.

The third reason for the ABA's call for a moratorium is found in the "longstanding patterns of racial discrimination... in courts around the country,"104 patterns of discrimination that have repeatedly been called to the attention of the judiciary and cited by anti-death penalty lawyers as reasons why the death penalty violates the Fourteenth A mendment's guarantee of equal protection. The A BA report cites research showing that defendants are more likely to receive a death sentence if their victim is white rather than black, ${ }^{105}$ and that in some jurisdictions, A frican-A mericans tend to receive the death penalty more often than do white defendants. ${ }^{106}$ The report calls for the development of "effective mechanisms" to eliminate racial prejudice in capital cases, yet does not identify what such mechanisms would be. ${ }^{107}$ Indeed, it is not clear that any such mechanisms exist.

The pernicious effects of race in capital sentencing are a function of the pervasiveness of racial prejudice throughout the society combined with the wide degree of discretion necessary to afford individualized justice in capital prosecutions and capital trials. Prosecutors with limited resources may be inclined to allocate resources to cases that attract the greatest public attention, which often will mean cases where the victim was white and his or her assailant black. Participants in the legal system-whether white or black-demonize young black males, seeing them as more deserving of death as a punishment because of their perceived dangerousness. ${ }^{108}$ These cultural effects clearly are not remediable. A s B lackmun noted in Callins,

102. 506 U .S. 390, 399 (1993) (quoting Patterson v. N ew Y ork, 432 U .S. 197, 208 (1977)).

103. See id. at 417.

104. A B A R eport, supra note 98, at 11, reprinted in A ppendix, supra note 35, at 228.

105. Seedavid Baldus et al., Equal Justice and The Death Penalty: a legal and EMPIRICA L A NA LY SIS 399-400 (1990).

106. See Samuel R. Gross \& Robert mauro, Death and Discrimination: Racial DISPARITIESIN CAPITA L SENTENCES 45 (1989).

107. A B A R eport, supra note 98 , at 14, reprinted in A ppendix, supra note 35, at 230.

108. See Judith Butler, Endangered/Endangering: Schematic Racism and White Paranoia, in REA DING R ODNEY KING/REA DING URBAN U PRISING 15 (R obert Gooding-Williams ed., 1993). 
[W ]e may not be capable of devising procedural or substantive rules to prevent the more subtle and often unconscious forms of racism from creeping into the system.... [D ]iscrimination and arbitrariness could not be purged from the administration of capital punishment without sacrificing the equally essential component of fairnessindividualized sentencing. ${ }^{109}$

\section{CONCLUSION}

What does all of this say about the meaning and significance of the A BA 's recommendation? In my view, while it appears that the $A B A$ is still willing to tinker with the machinery of death, in fact, the A B A 's indictment of the system of capital sentencing is pervasive and damning. No well-intentioned reformism can save that system. Taking its recommendation and report seriously reminds us that the post-Furman effort to rationalize death sentences has utterly failed; it has been replaced by a policy that favors execution while trimming away procedural protection for capital defendants. This situation only exacerbates the incompatibility of capital punishment and legality. Like J ustice Blackmun and the community of lawyers fighting to stop executions, the A BA has embraced the new abolitionism, eschewing a direct address to state violence and relying instead on an indirect, though nonetheless devastating, critique. The ABA provides legitimacy to those lawyers in the face of direct and persistent attacks. I ts endorsement of the new abolitionism may help sustain their efforts to speak to the future and call it to protect law by ending state killing.

In the end, the A BA 's embrace of the new abolitionism reveals a persistent, unalleviated anxiety about the state's ultimate form of violence, an anxious insistence that the state, though it comes into the world born of physical violence, or the violent disruptions of the existing order of things, ${ }^{110}$ transcend the violence of its origins. For the A BA, as well as for J ustice B lackmun, the rejection of the death penalty takes the form of an effort to prevent the erosion of the boundaries between state violence and its extra-legal counterpart. This effort, while speaking to some of the most pressing issues facing today's capital punishment system, recaptures the spirit of Furman. $Y$ et while it calls us back to Furman's critique of the practices of capital punishment, and to its doubts about whether those practices could be squared with the law's requirements, it radicalizes F urman by reminding all A mericans of this country's continuing inability, more than twenty-five years later, to get state killing right.

The A B A, in effect, has legitimated the crucial complaints voiced in today's abolitionist movement without itself reaching an overtly abolitionist conclusion. By speaking in the name of civic idealism rather than partisan engagement, it provides symbolic capital to those on the front lines in the battle against state killing. While there is little immediate prospect that its recom-

109. Callins v. Collins, 510 U .S. 1141, 1154-55 (1994) (Blackmun, J., dissenting from denial of certiorari to Callins v. Collins, 998 F.2d 260 (5th Cir. 1993)).

110. See Walter Benjamin, Critique of Violence, in REFLECTIONS: ESSAYS, A PHORISMS, AND A UTOBIOGRA PHICA L W RITING 300 (E dmund J ephcott trans., 1978). 
mended moratorium will come to pass, the A BA's action, at least for a time, helps secure the political space from which anti-death penalty lawyers can continue to call future generations some day to recapture and vindicate the spirit of Furman. 